\title{
Exploring trends in the relationship between child labour, gender and educational achievement in Latin America
}

\author{
Abigail Middel' (D); Kalyan Kumar Kameshwara' (D) ; Andrés Sandoval-Hernandez' \\ ${ }^{1}$ University of Bath, United Kingdom
}

Abstract. Participation in child labour, in both household and non-household activities, gender effects and low educational attainment remain challenges for countries in Latin America. Through hierarchical linear modelling of data from the OECD's Programme for International Student Assessment (PISA), this study seeks to explore the current cross-country trends in the relationship between educational attainment, child labour and gender. While non-household labour is found to have an effect, as per statistical significance and the magnitude, on educational achievement across all Latin American countries; participation in household labour is significant in only two countries (Peru and Uruguay). Girls are found to underperform compared to boys by a significant margin across Latin America. The later part of the study seeks to examine the interaction effects of gender and participation in labour activities. Results show that gender has no moderating effect, suggesting that the participation in work itself or workspace (household or non-household) does not influence or contribute to gender inequality in education outcomes. The explanatory factors for gender inequality in education outcomes is potentially rooted in a different sphere of influence which needs to be deciphered through deeper empirical investigation.

Keywords: child labour; gender; inequality; educational achievement; Latin America

Análisis de tendencias en la relación entre el trabajo infantil, el género y los logros académicos en Latinoamérica

Resumen. La participación de menores, tanto en tareas domésticas como no domésticas, los efectos del género y los bajos logros académicos siguen siendo un reto para los países de América Latina. A través del modelaje lineal jerárquico de datos del Programa Internacional de Evaluación de los Alumnos (PISA), este estudio busca explorar las tendencias entre los países en la relación entre los logros académicos, el trabajo infantil y el género. Si bien el trabajo fuera del hogar suele tener un efecto sobre los logros académicos en todos los países de Latinoamérica, tal como demuestran la importancia y la magnitud de las estadísticas; la participación en las tareas del hogar es relevante únicamente en dos (Perú y Uruguay). Se ha visto que las niñas obtienen peores resultados que los niños en un margen importante en toda Latinoamérica. La última parte del estudio busca analizar los efectos de interacción de género y participación en actividades laborales. Los resultados demuestran que el género no es un factor moderador, lo que sugiere que la participación en el trabajo o en el lugar de trabajo en sí mismo (en el hogar o fuera de él) no influye ni contribuye a la desigualdad de géneros en los resultados académicos. Los factores que explican la desigualdad en los resultados académicos se encuentran posiblemente en una esfera de influencia distinta que debe descifrarse mediante una investigación empírica más profunda.

Palabras clave. trabajo infantil; género; desigualdad; logros académicos; Latinoamérica.

Análise das tendências na relação entre o trabalho infantil, gênero e desempenho acadêmico na América Latina.

Resumo. A participação de menores, tanto em tarefas domésticas como não domésticas, os efeitos do gênero e o baixo rendimento escolar continuam sendo um desafio para os países da América Latina. Por meio de modelagem linear hierárquica de dados do Programa Internacional de Avaliação dos Alunos (PISA), este estudo busca explorar as tendências entre os países na relação entre desempenho acadêmico, trabalho infantil e gênero. Embora o trabalho fora de casa tenda a afetar o desempenho acadêmico em todos os países da América Latina, como mostra a importância e a magnitude das estatísticas, a participação nas tarefas domésticas é relevante apenas em dois (Peru e Uruguai). Viu-se que as meninas obtêm piores resultados que os meninos por uma margem significativa em toda a América Latina. A última parte do estudo busca analisar os efeitos da interação de gênero e a participação nas atividades de trabalho. Os resultados mostram que o gênero não é um fator moderador, sugerindo que a participação no trabalho ou no próprio local de trabalho (no lar ou fora dele) não influencia nem contribui para a desigualdade de gêneros nos resultados acadêmicos. Os fatores que explicam a desigualdade nos resultados acadêmicos estão possivelmente em uma esfera de influência diferente que deve ser decifrada por meio de uma pesquisa empírica mais profunda.

Palavra-chave: trabalho infantil, gênero; desigualdade; resultados acadêmicos; América Latina. 


\section{Introduction}

Academic achievement is important because it is strongly linked to positive outcomes in many other areas. Adults who report high educational achievement during their school time are more likely to have stable employment, have more employment opportunities, and earn higher salaries than those with lower educational achievement (Card, 1999). They are less likely to engage in criminal activity (Machin et al., 2011; Lochner \& Moretti, 2004), be more active as citizens (Lochner, 2011), and to be healthier (Bossuyt et al., 2004; Khang et al., 2004) and happier (Easterlin, 2003).

Factors negatively associated with poor educational outcomes are generally consistent across not just Latin America, but the globe. Lack of parental education is associated with lower attainment and higher dropout rates from high school (Barnard, 2004; Lee \& Bowen, 2006) and parental involvement and expectations play an important role (Arends-Kuenning \& Duryea, 2006; Driessen et al., 2005; Choi, 2008). Socioeconomic status is strongly associated with academic achievement (Nam \& Juang, 2009; Rearon, 2011; Altschul, 2012; Pfeffer, 2018; Ziol-Guest \& Lee, 2016) and belonging to an ethnic minority group is also strongly associated with poorer educational outcomes in many countries (Gillborn \& Mirza, 2000; Kao \& Thompson, 2003; Murillo, 2003; Archer \& Francis, 2006). Other factors such as the level of urbanisation is found to be negatively associated with educational outcomes in developing countries for a variety of reasons including the higher cost per student of providing education in rural areas (Behrman et al., 1999; Gould, 2007).

It's been argued that in Latin America, unlike in many developing countries, gender is no longer associated with educational outcomes. Female students are reported to have not faced disadvantage in terms of enrolment across the region for over 30 years (Ahuja \& Filmer, 1995) and have even begun to overtake male students, receiving equal or higher grades than males (Grant \& Behrman, 2010). Along with factors mentioned above, child labour is found to be a significant predictor of poor educational outcomes including enrolment, attendance, grade repetition and attainment (Montmarquette et al., 2007; Heymann et al., 2013; Psacharopoulos, 1997; Assaad et al., 2010; Putnick \& Bornstein, 2016; Eckstein \& Wolpin, 1999; Parent, 2006; Gunnarsson et al., 2006). Latin American countries have large numbers of children working with varying legislation (Appendix 1 ) as well as social programmes in place aimed at reducing this practice.

In terms of enforcement of child labour laws, none of the Latin American countries in this study have a sufficient number of labour inspectors as per technical advice from the International Labour Organisation (ILO) 
of a ratio of 1 inspector for every 15,000 workers. In Colombia, Dominican Republic and Peru there are less than half the recommended number of inspectors (ILAB, 2020). Not all countries have data available on the number of inspections conducted and even fewer report the number of child labour violations found and for which penalties were imposed and subsequently collected. In Chile and the Dominican Republic two of the countries for which we have some data, all child labour violations found had penalties imposed; however, in Chile less than half of these penalties were collected. In Colombia of 247 labour violations found in 2017, only 15 had penalties imposed (ILAB, 2020).

All countries have various social programmes aimed at reducing child labour. These include programmes which strengthen the employability of family members of at risk children (Walking Together for the Eradication of Child Labor, Chile), conditional cash transfer programs (More Families in Action, Colombia; Let's Get Ahead Program, Costa Rica; the Together Program, Peru), work and study programmes (I Study and Work, Uruguay), extension of the school day (Dominican Republic), educational and psychological help to at risk families (Carabayllo Project, Peru), targeting children in rural areas (Huánuco Project Peru; Houses of Joy Costa Rica) and education on children's rights (Present Against Child Labor, Colombia) (ILAB, 2020).

One of the challenges in studying child labour is that of defining child labour itself. The difficulty in arriving at a uniform definition is the fact that child labour intersects with local contextual and cultural factors. This complexity intensifies as we approach the adolescent years of the child, when his or her physical capacity to undertake work coincides with the most crucial secondary school years and, in many countries, legal working age. Minimum working age legislation often comes in the form of ratification of the Minimum Age Convention set forth by the ILO, who proffer their own definition of child labour.

The ILO notes that not all work undertaken by children can be classified as "child labour" and define it only as, "work that deprives children of their childhood, their potential and their dignity, and that is harmful to physical and mental development and/or interferes with their schooling." (ILO, 1996). Some kinds of work undertaken by children and adolescents are in fact considered positive. The ILO includes in this category activities such as household chores, helping in a family business or earning an allowance outside of school hours. They note that these activities "contribute to children's development and to the welfare of their families; they provide them with skills and experience and help to prepare them to be productive members of society during their adult life." (ILO, 1996) 
Whether specific forms of work outside of the above can be considered 'child labour' is contingent on the age of the child, the nature and hours of the work undertaken and the working conditions and the cultural and legal contexts. This is then contingent on the individual country and the sector the work falls under (ILO, 1996). The ILO specifically considers work child labour if it has an adverse effect on a child's education by "depriving them of the opportunity to attend school; obliging them to leave school prematurely; or requiring them to attempt to combine school attendance with excessively long and heavy work." (ILO, 1996).

The definition of child labour is a complex one, and data available does not always allow operationalisation of it as per ILO guidelines. For the purpose of this analysis, child labour is understood as any labour undertaken by children (who in this study are aged 15) before or after school. Similar to previous studies on child labour in Latin America (Gunnarsson et al., 2006; Psacharopoulos, 1997), this study lacks information on the nature of work undertaken as well as the hours.

There is a potential argument made for a broader definition of child labour which is not tied to the specific nature of the work nor the number of hours. The image of a child working for long hours outside the home that informs legislation and social programmes aimed at its reduction, is not the profile of child labourers in many countries and particularly misrepresents the labour of girls (Assaad et al., 2010). Children are often engaged in work that is not captured by traditional definitions of work (i.e. market work) for example unpaid agricultural work in family enterprises. In doing so, research ignores the potential for responsibilities inside the household to effect educational attainment, in fact any work which interferes with human capital production that would benefit children and society should be considered (Putnick \& Bornstein, 2016; Assaad et al., 2010). In addition, this kind of unpaid household work is said to be gendered and traditional definitions of work significantly misrepresent the work undertaken by girls (Putnick \& Bornstein, 2016; Levison, 2000). This complexity can only be understood and tackled, if need be, by studying child labour in each context and examining the factors local forces that shape the process.

Therefore, it is important to empirically study how child labour interacts with influential factors such as gender. This paper sets out to achieve just that in the context of Latin America. It seeks to explore the trends and effects in/of participation of child in labour forms categorised broadly as household labour and non-household labour and its effect on education. 


\section{Literature review}

There are various reasons posited for children's' participation in work. Using simultaneous equation models fitted to Indian data, Rosenzweig and Evenson (1977) analysed family decision making regarding fertility and the allocation of children's time to labour and education. They concluded that a high return on raw child labour as opposed to investment in skills acted as a motivation for the creation of large families. In analysis of data from Venezuela, Psacharopoulos (1997) found a similar trend - that the decision to work was associated with a larger family size. However, data from Botswana on the activities of youth led Chernikovsky et al. (1985) to conclude that there is in fact no trade-off between children's schooling and fertility.

Child's gender, familial wealth and composition and rural dwelling are important predictors of child labour. In an analysis of data from Latin America Psacharopoulos (1997) found working children were mostly male, indigenous, and from poorer female-headed households and their earnings contributed a significant amount of household income, amounting to $13 \%$ and $27 \%$ in Bolivia and Venezuela respectively. Analysis of Canadian data showed that student gender and education of parents most significantly predicted students' preference for labour market participation over schooling. As well as male students and students with parents with no post-secondary education, female students with children and students from single parent families were also overrepresented among those who drop out to pursue work (Montmarquette et al., 2007). In addition, several studies have found that residing in an urban area reduces the probability of children undertaking paid work (Psacharopoulos, 1996; Assaad et al., 2010).

Macro factors like minimum wage and levels of unemployment are strongly associated with child labour. The decision to drop out of school to pursue work is significantly affected by minimum wage (measured in real terms) - when students who are unsure as to whether to finish high school can earn a high minimum wage in the labour market, they tend to conclude there is little to gain from continuing their education (Montmarquette et al., 2007). As well as a high minimum wage, low unemployment rate can also cause students who may not be inclined to drop out, to do so under these particular conditions. Montmarquette et al. (2007) evidence this in their finding that the effect of these macroeconomic variables was stronger for those who express a preference for schooling (and therefore under normal conditions would not be inclined to drop out).

Studies of various Latin American countries in particular have shown that legislation has little effect on children's involvement in the labour force. Psacharopoulos' (1997) analysis revealed significant partici- 
pation in the labour market among children who should be prevented from it by compulsory education or working age legislation. Similar evidence was found in Brazil by Bargain and Boutin (2017) and in data from 59 countries including Venezuela, the Dominican Republic and Bolivia by Edmonds and Shrestha (2012). Legislation often fails in eliminating child labour in its entirety as legislation does not cover the entire economy or only applies to specific activities or sectors (Boockmann, 2010). A ban that applies only to certain sectors also leads to a reduction in child wages due to the subsequent excess supply of child labour in sectors not enforcing the ban (Basu \& Van, 1998). In addition if productivity and wages are higher in the sector where the legislation is enforced (e.g. industry) it pushes children into low paid low productivity employment such as agriculture. Households rely on this income need to maintain it. This means that more hours would be worked in order for household wealth not to be negatively affected meaning less time allocated to education.

The reduction of income also has a subsequent effect on other children within the family - although substantial working hours represent a clear detriment to a child's education, their earnings (which as previously discussed can be as high as $27 \%$ of household income) increase the probability that their siblings will attend school (Basu \& Tzannatos, 2003). If wages are depressed, instead of more hours worked by one child, budget-constrained households may send more children to work, and legislation has had the exact opposite of the desired effect. A rise in adult wages is needed to offset that negative effects on household wealth to avoid the above consequences (Boockmann, 2010). This is also the case if the financial consequences of a ban (penalties or bribes) are shouldered by families (Basu \& Van, 1998).

\subsection{Household Labour}

In addition the prohibition of child labour (through minimum legal working age laws) is rarely applied uniformly across all activities. Thus, it may in fact merely lead to the reallocation of child labour into unregulated sectors such as family businesses or work happening inside the household where these laws do not apply or are even more difficult to enforce (Bargain \& Boutin, 2017). Using a two-sector model of employment in which legislation completely eliminates child labour, Basu (2005) found that a ban via minimum age legislation in this model instead pushed children into unregulated work. There are three conditions identified by Edmonds and Shrestha (2012) as necessary for sector reallocation to be neutral after a ban in the regulated sector. Firstly, that child and adult labour are exact substitutes subject to a productivity shifter (based on Basu and Van's (1998) 'substitution axiom'). The second condition is 'non-saturation' - that adult and child labour can be 
easily substituted between productive tasks within the household. Thirdly is the need for 'competitive adult labour markets' - the free movement of adult labour between the household and the labour market, otherwise children's work may merely be moved inside the home. Despite this, the paid work undertaken by children outside the home has received the most empirical attention (Putnick \& Bornstein, 2016) and literature on child labour often ignores the potential for responsibilities inside the household to affect educational attainment.

Levison (2000) further argues that the traditional definition of work used to define child labour distinguishes arbitrarily between activities that are similar. She gives the example of food preparation, which if happening in a market stall or unpaid in a family enterprise is considered work, but the same activity is not considered work if undertaken for the purpose of household consumption. In the context of labour force statistics or national accounts the distinction between household / domestic work and market work is useful but causes biases when trying to understand the effect of child labour on schooling (Levison, 2000). Small jobs or chores may be beneficial for children, but the issue is with all work, whether included in the traditional definition or not, that interferes with children's education or wellbeing (Assaad et al. 2010).

\subsection{Gender}

As previously discussed, the definition used when assessing the relationship between children's work and educational attainment matters greatly, particularly for girls - gender differences in both the incidence and determinants of work are misrepresented when a traditional definition of work (i.e. market work) is used (Levison 2000). Overall, for middle- and low-income countries, there are higher rates of girls' labour inside the home and higher rates of labout inside the home for boys, which often reflects "macrosystem-level gender inequality" (Putnick \& Bornstein, 2016, p5). The high amount of household labour carried out by girls can be attributed to the cultural expectation that girls will be mothers and homemakers and thus early involvement in household work acts as preparation for these adult roles (Assaad et al., 2010).

As well as cultural, the reason is economic - in a number of the low- to middle- income countries studied by Putnick \& Bornstein (2016) the levels of education and rates of employment are much lower for women than for men - in the face of these limited economic opportunities for adult women, parents may encourage girls to assume responsibilities within the household to prepare them for their likely adult role as a homemaker. It can 
also be considered a rational decision by girls and adolescents themselves, who are aware of their incredibly limited access to the paid labour market (Assaad et al., 2010). In the same vain, boys' work outside the home allows them to develop skills that may apply to their adult work. In countries with better national gender equality, participation of boys and girls in excessive chores is similar (Putnick \& Bornstein, 2016).

\subsection{Educational outcomes}

Studies have examined the effect of hours worked on educational outcomes measured by enrolment, attendance, drop out / graduation rates, grade repetition, years of schooling and in few cases, test results. Household and non-household labour has been found to negatively affect both enrolment and attendance (Beegle et al., 2009; Assad et al., 2010). In a study of developing countries only, Guarcello et al. (2008) found that working children faced an attendance disadvantage of $10 \%$ or above in 56 out of 60 countries, and in 10 of those countries the disadvantage was as high as $30 \%$. Working children also have a disadvantage in total years of schooling compared to non-working children. In Latin American countries, the difference in educational attainment between nonworking and working children begins as young as aged six and then increases rapidly - by the age of 14 (legal working age) Venezuelan working children have a deficiency of 2 years and Bolivian working children 1.4 years (rising to 2.5 by the age of 18) (Psacharopoulos, 1997).

However, measuring educational outcomes in this way has limitations. Attendance, enrolment and even years of schooling do not measure learning. Children might continue to attend school every day due to compulsory schooling legislation however working children may be too fatigued to study effectively in school nor have the time nor energy to study afterwards (Gunnarsson et al., 2006); the effects of which are not captured by these measures.

Various studies have found a strong link between work and high school drop-out rates (Parent, 2006; Montmarquette et al., 2007; Eckstein and Wolpin, 1999). While dropping out of high school to pursue work may be due to economic necessity of the household with child income often accounting for large percentage of a household's income (Psacharopoulos, 1997). Working during high school may cause a child to lag behind in their schoolwork to the point where dropping out in favour of entering the labour market full time is preferable (Eckstein and Wolpin, 1999). However, assessing educational outcomes as completion (graduation) or non-completion (drop-out) of high school does not take into account working children who stay in school and their possible lower achievement and the limit that pla- 
ces on future pursuits. It has been noted in several studies including Marsh (1991) and Barone (1993) that young people working more than 20 hours per week while in school were much less likely to pursue higher education.

Educational attainment can be assessed through grade attainment. Although grade failure and repetition are associated with the same causal factors as children's participation in the labour market, working almost doubles the likelihood of failing a grade (Psacharopoulos, 1997). Beegle et al. (2009) found that child labour was significantly associated with a reduction of the highest grade attained. Although grade attainment may be a more nuanced measure than high school completion, the main limitation is the difficulty of cross-country comparison due to substantial difference in schooling across countries including the way in which grade attainment is assessed. In their study of Latin America, Gunnarsson et al. (2006) used results from mathematics and literacy tests and found that children who almost never work had a $22 \%$ and $27 \%$ advantage in mathematics and language respectively over working children. Although the use of test scores is arguably a better measure of educational outcomes as it measures learning, the use of pooled regression does not sufficiently address the issue of cross-country invariance.

\section{Significance of the study}

Previous studies examining the effect of child labour have largely focused on school enrolment, attendance, dropouts, grade repetition and aspirations. These can be considered proxies, and proxies for only schooling, not addressing the actual goal of schooling itself - learning. There is also a dearth in exploitating the large-scale cross-country surveys which offer a valuable snapshot on the latest trends in child labour, gender and education.

This study would help bridge the gap in literature by examining the association between child labour, and its interaction with gender, and educational attainment measured via test scores. In addition to that, it gives a more comprehensive picture of the trends in Latin America by giving a comparative analysis involving various countries. There are very few studies focused solely on Latin America, and the majority of those that have done so, or included Latin America in aggregate or pooled data, have used data from more than two decades ago. Latin America has undergone rapid change over the last 20 years, and although inequality persists, it has been declining in many countries (López-Calva \& Listig, 2010). However, whilst access to primary and secondary education has been expanded, access to tertiary education, the next stage in Latin America's "educational upgrading" (Grynspan, 2010, p.vii), could be affected due to low educational attainment 
in secondary schools, (López-Calva \& Listig, 2010), precisely the outcome variable measure in this study, and a crucial factor that studies examining purely schooling would miss.

This study exploits the variance in labour participation levels, and student learning levels, both within and between countries to estimate its association. The study employs multilevel analysis, which accounts for clustering, to identify the contribution (positive or negative) and significance of child labour, and its association with gender, in shaping student test scores. This study aims to add robust empirical evidence to the body of knowledge on the status of child labour participation and its effect on child's education. This evidence is important through its uniqueness - it does not originate from a study focused exclusively on child labour or household survey but from a school survey focusing on education.

\section{Research questions}

This study uses large-scale datasets from OECD's PISA to explore the trends and effects of labour practices among 15-year-old children on their education outcomes in seven Latin American countries. The study exploits PISA 2015 survey data which captures if the student is engaged in household or non-household labour in all of the seven Latin American countries. It seeks to examine the effects of child labour participation (for household and non-household labour separately) on learning achievements in each of the seven countries, after controlling for various individual, household and school effects. Additionally, the study also examines if the participation and effects of participation in labour is moderated by individuals' gender.

1. What are the patterns in child labour participation (in household and non-household labour) across the sample of Latin American countries? How is it distributed along the lines of gender?

2. Does participation in household or/and non-household labour have any significant influence on student's learning levels? If so, what is the magnitude of effect in each country?

3. Does gender moderate the effect of labour participation on student attainment? 


\section{Data and methods}

There were 72 countries in total which participated in PISA in 2015 and eight from Latin America. They include Brazil, Chile, Costa Rica, Colombia, Dominican Republic, Mexico, Peru and Uruguay. PISA follows a complex sampling design strategy. The schools are selected using systematicrandom PPS (probability proportional to size) sampling. In the next stage, students who are 15 years old are randomly selected from each school. There is data collected at the student level, teacher level and school level from all the sampled schools and students (OECD, 2017).

Along with collecting information about student and home background, PISA also surveys if students participate in household and nonhousehold labour activities. These are the main variables of interest in this study. They are captured for each student in the sample in all the PISA participating countries from Latin America. Each of the students is administered an assessment to capture his or her learning levels in mathematics, science, reading, financial literacy and collaborative problem solving. Due to the length of the assessment, the student undertakes only a part of the test in each subject and based on their performance, the final scores are imputed as plausible values. The mathematics scores are chosen as proxy for student learning and achievement in this study. With mathematics achievement as the outcome, two-level hierarchical regression models are constructed for each country with student at one level and school at another level.

Hierarchical regression analysis is chosen over OLS linear regression model to account for the clustering effects of students in a school (Goldstein 2011). This is due to the correlation between student performances from the same school. Hierarchical models would produce unbiased and robust estimates taking into consideration that student scores in the sample are not independent of each other. The inferences made from the analysis of PISA 2015 can be generalisable to a country level due to the representative sample and the sampling weights included as part of the analysis. In order to account for the imputation uncertainty derived from the PISA complex assessment design, the ten plausible values provided in the data set for the maths scores were used simultaneously in all the analyses (Rutkowski, et al., 2010). Furthermore, following the procedure suggested by Rutkowski and colleagues (2010), each level was weighted separately for all the models

The first model $\left(M_{1}\right)$ is constructed for each of the seven countries, to examine the effect of participation in labour activities on learning achievement in mathematics: 
Maths Scores $\left(y_{i j}\right)=$

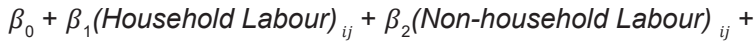

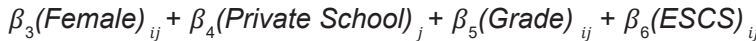

$$
\begin{aligned}
& +\beta_{7} \text { (Motivation levels) }_{i j}+\beta_{8} \text { (Expected Occupational Status) }_{i j}
\end{aligned}
$$

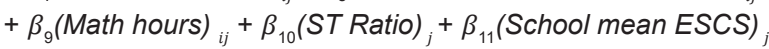

$$
\begin{aligned}
& +e_{i j}+u_{j} \\
& e_{i j} \sim N\left(0, \sigma_{\mathrm{e}}^{2}\right) ; u_{j} \sim N\left(0, \sigma_{\mathrm{u}}^{2}\right)
\end{aligned}
$$

While the variables of interest are mainly household, nonhousehold labour and gender of the student, it is necessary to control for various student and school-level characteristics. The school-level variables accounted for in the modelling are the type of school (public or private), the Student-Teacher ratio of the school and most importantly the average of social, economic and cultural statuses (ESCS) of all sampled children in the school. The individual level characteristics controlled for in the above and below equations are the grade in which the student is studying, motivational levels, aspiration levels (desired occupation status) and the number of hours dedicated in total to study the subject of assessment (mathematics). These covariates are chosen from literature as they have shown to demonstrate a significant contribution in explaining the variance of the outcome variable (student achievement). The Model $\left(\mathrm{M}_{1}\right)$ assists in answering the second research question on the significance and effect of labour participation in student learning.

In order, to answer the third research problem of this paper, the following models $\left(M_{2}\right)$ and $\left(M_{3}\right)$ are constructed. In order to examine if gender moderates the effect of labour participation on student learning, an interaction term, between household labour and female dummy, between non-household labour and male dummy, is added to the above model.

Maths Scores $\left(y_{i j}\right)=$

$$
\begin{aligned}
& \left.\beta_{0}+\gamma \text { (Household Labour }{ }^{*} \text { Female }\right)+\beta_{1} \text { (Household Labour) } \\
& { }_{i j}+\beta_{2} \text { (Non-household Labour) }_{i j}+\beta_{3} \text { (Female) }_{i j}+\beta_{4} \text { (Private }^{\text {(N) }} \\
& \text { School) }{ }_{j}+\beta_{5} \text { (Grade) }_{i j}+\beta_{6}(\text { ESCS })_{i j}+\beta_{7} \text { (Motivation levels) } \\
& { }_{i j}+\beta_{8} \text { (Expected Occupational Status) }_{i j}+\beta_{9} \text { (Math hours) }_{i j}+
\end{aligned}
$$

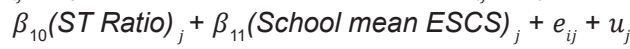

$$
\begin{aligned}
& e_{i j} \sim N\left(0, \sigma_{\mathrm{e}}^{2}\right) ; u_{j} \sim N\left(0, \sigma_{\mathrm{u}}^{2}\right)
\end{aligned}
$$

Maths Scores $\left(y_{i j}\right)=\quad \beta_{0}+\gamma\left(\right.$ Non-household Labour ${ }^{*}$ Male $)+\beta_{1}($ Household Labour $)$ ${ }_{i j}+\beta_{2}$ (Non-household Labour) $_{i j}+\beta_{3}(\text { Female })_{i j}+\beta_{4}$ (Private $^{\text {(N) }}$

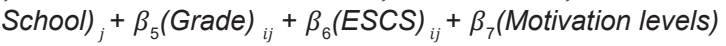

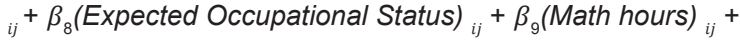

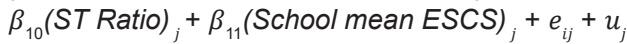

$$
e_{i j} \sim N\left(0, \sigma_{\mathrm{e}}^{2}\right) ; u_{j} \sim N\left(0, \sigma_{\mathrm{u}}^{2}\right)
$$


Female is included as a dummy in model $2\left(\mathrm{M}_{2}\right)$ as it is often observed that girls engage more in household labour and it would be plausible to examine if female moderates the effect in the case of household labour participation. Likewise, following the similar reasoning, male is added as a dummy for model $3\left(\mathrm{M}_{3}\right)$ in the case of non-household labour. These models are similarly constructed for each country with the controls from first model $\left(M_{1}\right)$ intact.

\section{Results}

The trends and distribution of participation in labour activities, in household and non-household domains, in seven ${ }^{[i]}$ Latin American countries are demonstrated by the following descriptive statistics in (Table 1) and (Table 2).

\begin{tabular}{lrrrr} 
Table 1 & \multicolumn{3}{c}{ Non Household Labour (\%) } \\
\hline \multicolumn{1}{c}{ Country } & \multicolumn{1}{c}{ Household Labour (\%) } & \multicolumn{2}{c}{ No } & Yes \\
\cline { 2 - 5 } Chile & No & Yes & 75.45 & 24.55 \\
Colombia & 33.56 & 66.44 & 55.54 & 44.46 \\
Costa Rica & 22.98 & 77.02 & 80.79 & 19.21 \\
Dom Rep. & 34.16 & 65.84 & 58.66 & 41.34 \\
Mexico & 15.63 & 84.37 & 70.5 & 29.5 \\
Peru & 17.46 & 82.54 & 68.24 & 31.76 \\
Uruguay & 10.3 & 89.7 & 67.59 & 32.41
\end{tabular}

Source: authors' descriptive statistics from PISA 2015.

All the Latin American countries studied here have at least $65 \%$ of the sample taking part in household labour and not more than $45 \%$ involved in non-household labour. The highest participation in household labour is found in Peru, followed closely by Dominican Republic and Mexico. In the case of non-household labour, Colombia has the highest percentage, immediately followed by Dominican Republic. Costa Rica has the lowest participation of the sample in both household and non-household labour. Not far below Costa Rica, Chile is found to have the second lowest participation levels in both domains. However, it cannot be said if having a higher or lower percentage of children involved in labour, has (or does not have) an effect on one's education. It remains to be seen if labour participation has any actual effect (positive or negative) on student's education and how this could be shaped by different contextual factors. 
Table 2

\begin{tabular}{llcccc}
\hline \multirow{2}{*}{ Country } & Gender & \multicolumn{2}{c}{ Household Labour } & \multicolumn{2}{c}{ Non-Household Labour } \\
\cline { 3 - 6 } Chile & & No & Yes & No & Yes \\
\cline { 3 - 6 } Columbia & Male & 1,046 & 2,019 & 2,129 & 921 \\
& Female & 1,026 & 2,083 & 2,502 & 586 \\
Costa Rica & Male & 1,251 & 3,906 & 2,531 & 2,623 \\
& Female & 1,255 & 4,492 & 3,514 & 2,217 \\
Dominican Rep & Male & 946 & 1,692 & 1,976 & 657 \\
& Female & 898 & 1,862 & 2,377 & 378 \\
Mexico & Male & 311 & 1,341 & 800 & 836 \\
& Female & 234 & 1,600 & 1,222 & 589 \\
Peru & Male & 634 & 2,634 & 2,022 & 1,237 \\
& Female & 521 & 2,827 & 2,630 & 710 \\
Uruguay & Male & 317 & 2,503 & 1,680 & 1,134 \\
& Female & 240 & 2,346 & 1,994 & 576 \\
& Male & 474 & 1,781 & 1,296 & 938 \\
& Female & 523 & 2,047 & 1,922 & 605
\end{tabular}

Source: authors' descriptive statistics from PISA 2015.

Therefore, the first research question is answered through the descriptive statistics by depicting an overall picture of percentages and frequencies of participation rates in household and non-household labour activities and how they are split based on gender. The results of the hierarchical linear models for each country are represented below. The estimates and their standard errors of variables of interest and other student and school level covariates are listed in Table 3.

Table 3

\begin{tabular}{lccccccc}
\hline $\begin{array}{c}\text { Student } \\
\text { achievement }\end{array}$ & Chile & Colombia & $\begin{array}{c}\text { Costa } \\
\text { Rica }\end{array}$ & Dom Rep. & Mexico & Peru & Uruguay \\
\hline $\begin{array}{l}\text { Household } \\
\text { Labour }\end{array}$ & -1.31 & -4.51 & 1.25 & 3.18 & 1.56 & $-8.27^{* *}$ & $-10.74^{* * *}$ \\
\hline $\begin{array}{l}\text { Non-Household } \\
\text { Labour }\end{array}$ & $-27.21^{* * *}$ & $-23.29^{* * *}$ & $-18.13^{* * *}$ & $-25.59^{* * *}$ & $-22.09^{* * *}$ & $-25.20^{* * *}$ & $-25.14^{* * *}$ \\
\hline Female & $(-3.47)$ & $(-2.41)$ & $(-3.14)$ & $(-2.97)$ & $(-2.84)$ & $(-2.7)$ & $(-3.54)$ \\
\hline Private & $-28.90^{* * *}$ & $-26.34^{* * *}$ & $-23.22^{* * *}$ & $-12.68^{* * *}$ & $-13.86^{* * *}$ & $-20.53^{* * *}$ & $-25.64^{* * *}$ \\
& $(-3)$ & $(-2.71)$ & $(-3.17)$ & $(-3.03)$ & $(-2.33)$ & $(-2.61)$ & $(-3.88)$ \\
\hline Grade & -4.84 & 0.68 & -2.59 & 2.82 & -11.5 & -3.75 & -1.76 \\
& $(-9.79)$ & $(-7.36)$ & $(-10.21)$ & $(-11.24)$ & $(-9.11)$ & $(-7.57)$ & $(-9.56)$ \\
\hline
\end{tabular}




\begin{tabular}{|c|c|c|c|c|c|c|c|}
\hline $\begin{array}{c}\text { Student } \\
\text { achievement }\end{array}$ & Chile & Colombia & $\begin{array}{l}\text { Costa } \\
\text { Rica }\end{array}$ & Dom Rep. & Mexico & Peru & Uruguay \\
\hline \multirow[t]{2}{*}{ ESCS } & $9.50^{* * *}$ & $5.47^{* * *}$ & $6.64^{* * *}$ & $5.78^{* * *}$ & $4.15^{* * *}$ & $6.96^{* * *}$ & $8.55^{* * *}$ \\
\hline & $(-1.58)$ & $(-1.6)$ & $(-1.2)$ & $(-1.88)$ & $(-1.25)$ & $(-1.58)$ & $(-1.96)$ \\
\hline \multirow{2}{*}{$\begin{array}{l}\text { Motivational } \\
\text { Level }\end{array}$} & 1.19 & $8.69 * * *$ & 2.29 & $5.33^{* *}$ & $6.39 * * *$ & $11.03^{* * *}$ & $9.21^{* * *}$ \\
\hline & $(-1.55)$ & $(-2.01)$ & $(-2.1)$ & $(-2.13)$ & $(-1.84)$ & $(-1.72)$ & $(-1.69)$ \\
\hline \multirow{2}{*}{$\begin{array}{l}\text { Exp Occupatio- } \\
\text { nal Status }\end{array}$} & $0.55^{* * *}$ & $0.22^{* * *}$ & -0.08 & 0.07 & $0.28^{* * *}$ & $0.58^{* * *}$ & $0.36^{* * *}$ \\
\hline & $(-0.1)$ & $(-0.07)$ & $(-0.06)$ & $(-0.1)$ & $(-0.07)$ & $(-0.08)$ & $(-0.08)$ \\
\hline \multirow[t]{2}{*}{ Maths hours } & -0.11 & 0.49 & 1.63 & -0.76 & 0.79 & 0.17 & $2.33^{* *}$ \\
\hline & $(-0.42)$ & $(-0.53)$ & $(-1.1)$ & $(-0.47)$ & $(-0.69)$ & $(-0.44)$ & $(-1.12)$ \\
\hline \multirow{2}{*}{$\begin{array}{l}\text { Student-Teacher } \\
\text { Ratio }\end{array}$} & 0.78 & -0.33 & 0.05 & 0.15 & -0.08 & $0.36^{*}$ & -0.12 \\
\hline & $(-0.58)$ & $(-0.23)$ & $(-0.19)$ & $(-0.2)$ & $(-0.21)$ & $(-0.21)$ & $(-0.24)$ \\
\hline \multirow{2}{*}{$\begin{array}{l}\text { School mean } \\
\text { (ESCS) }\end{array}$} & $30.43^{* * *}$ & $19.92^{* * *}$ & $22.06^{* * *}$ & $26.42^{* * *}$ & $17.69^{* * *}$ & $19.94^{* * *}$ & $32.18^{* * *}$ \\
\hline & $(-5.22)$ & $(-5.6)$ & $(-4.37)$ & $(-7.82)$ & $(-4.46)$ & $(-4.12)$ & $(-6.35)$ \\
\hline \multirow[t]{2}{*}{ Constant } & $430.44^{* * *}$ & $448.70^{* * *}$ & $456.64^{* * *}$ & $377.08^{* * *}$ & $436.17^{* * *}$ & $400.88^{* * *}$ & $476.60^{* * *}$ \\
\hline & $(-13.69)$ & $(-11.24)$ & $(-8.56)$ & $(-16.12)$ & $(-12.01)$ & $(-11.33)$ & $(-11.86)$ \\
\hline \multirow[t]{2}{*}{ Ins1_1_1 } & $3.31^{* * *}$ & $3.23^{* * *}$ & $3.29 * * *$ & $3.09 * * *$ & $3.27^{* * *}$ & $3.16^{* * *}$ & $3.27^{* * *}$ \\
\hline & $(-0.09)$ & $(-0.08)$ & $(-0.1)$ & $(-0.19)$ & $(-0.11)$ & $(-0.08)$ & $(-0.09)$ \\
\hline \multirow[t]{2}{*}{ Insig_e } & $4.09 * * *$ & $4.03^{* * *}$ & $3.96^{* * *}$ & $3.91^{* * *}$ & $4.10^{* * *}$ & $4.08^{* * *}$ & $4.12^{* * *}$ \\
\hline & $(-0.01)$ & $(-0.01)$ & $(-0.01)$ & $(-0.03)$ & $(-0.02)$ & $(-0.02)$ & $(-0.02)$ \\
\hline Sample size $(n=)$ & 4,529 & 7,647 & 4,803 & 2,370 & 5,734 & 4,869 & 3,782 \\
\hline
\end{tabular}

Standard errors in parentheses *** $p<0.01,{ }^{* *} p<0.05,{ }^{*} p<0.1$

Source: authors' work.

Household labour is not found to be significant (with 95\% confidence levels) in shaping students learning except in the contexts of Peru and Uruguay. In these contexts, participating in household labour is shown to have a higher magnitude of effect than ones socio-economic and cultural status. Non-household labour participation, however, is found to be highly significant (with 99\% confidence levels) and has a remarkable negative effect on student learning. This pattern is found in all the seven Latin American countries. These findings lead to the next question if the effects of nonhousehold labour and household labour (in Peru and Uruguay) on student achievement are moderated by the individual's gender. In other words, the question can be rephrased as to understand if the gender effects (of being a female) on achievement, as seen in the above table, is influenced/moderated by male or female's participation in labour activities. The following tables (Table 4 and Table 5) aid in addressing the follow up question. 
Table 4

\begin{tabular}{|c|c|c|c|c|c|c|c|}
\hline $\begin{array}{c}\text { Student } \\
\text { achievement }\end{array}$ & Chile & Colombia & $\begin{array}{l}\text { Costa } \\
\text { Rica }\end{array}$ & Dom Rep. & Mexico & Peru & Uruguay \\
\hline \multirow{2}{*}{$\begin{array}{l}\text { Female*Household } \\
\text { Labour }\end{array}$} & -2.87 & -1.95 & -0.88 & 0.2 & 1.14 & -2.32 & 8.87 \\
\hline & $(-5.47)$ & $(-5.26)$ & $(-4.01)$ & $(-7.35)$ & $(-5.53)$ & $(-6.91)$ & $(-6.78)$ \\
\hline \multirow[t]{2}{*}{ Female } & $-26.94^{* * *}$ & $-24.82^{* * *}$ & $-22.64^{* * *}$ & $-12.84^{* *}$ & $-14.80^{* * *}$ & $-18.44^{* * *}$ & $-32.58^{* * *}$ \\
\hline & $(-4.87)$ & $(-5.14)$ & $(-3.8)$ & $(-6.3)$ & $(-5.37)$ & $(-6.98)$ & $(-6.5)$ \\
\hline \multirow[t]{2}{*}{ Household Labour } & 0.15 & -3.47 & 1.71 & 3.09 & 1.06 & -7.24 & $-15.70^{* * *}$ \\
\hline & $(-3.96)$ & $(-4.04)$ & $(-3.51)$ & $(-6.01)$ & $(-4.54)$ & $(-5.02)$ & $(-5.74)$ \\
\hline \multirow{2}{*}{$\begin{array}{l}\text { Non-Household } \\
\text { Labour }\end{array}$} & $-27.31^{* * *}$ & $-23.34^{* * *}$ & $-18.17^{* * *}$ & $-25.58^{* * *}$ & $-22.07^{* * *}$ & $-25.23^{* * *}$ & $-24.88^{* * *}$ \\
\hline & $(-3.45)$ & $(-2.42)$ & $(-3.15)$ & $(-2.97)$ & $(-2.83)$ & $(-2.72)$ & $(-3.58)$ \\
\hline \multirow[t]{2}{*}{ ESCS } & $9.51^{* * *}$ & $5.46^{* * *}$ & $6.63^{* * *}$ & $5.78^{* * *}$ & $4.15^{* * *}$ & $6.95^{* * *}$ & $8.49 * * *$ \\
\hline & $(-1.58)$ & $(-1.61)$ & $(-1.2)$ & $(-1.88)$ & $(-1.26)$ & $(-1.58)$ & $(-1.95)$ \\
\hline \multirow[t]{2}{*}{ Private } & -4.87 & 0.7 & -2.57 & 2.82 & -11.5 & -3.77 & -1.77 \\
\hline & $(-9.76)$ & $(-7.36)$ & $(-10.24)$ & $(-11.24)$ & $(-9.11)$ & $(-7.56)$ & $(-9.62)$ \\
\hline \multirow[t]{2}{*}{ GRADE } & $30.82^{* * *}$ & $23.70^{* * *}$ & $21.62^{* * *}$ & $17.97^{* * *}$ & $18.47^{* * *}$ & $22.75^{* * *}$ & $27.93^{* * *}$ \\
\hline & $(-3.07)$ & $(-1.14)$ & $(-2.02)$ & $(-1.8)$ & $(-3.89)$ & $(-1.41)$ & $(-2.21)$ \\
\hline \multirow[t]{2}{*}{ Motivational Level } & 1.18 & $8.67^{* * *}$ & 2.29 & $5.33^{* *}$ & $6.40^{* * *}$ & $11.01^{* * *}$ & $9.20^{* * *}$ \\
\hline & $(-1.55)$ & $(-2)$ & $(-2.1)$ & $(-2.13)$ & $(-1.84)$ & $(-1.72)$ & $(-1.69)$ \\
\hline \multirow{2}{*}{$\begin{array}{l}\text { Exp Occupational } \\
\text { Status }\end{array}$} & $0.55^{* * *}$ & $0.22^{* * *}$ & -0.08 & 0.07 & $0.28^{* * *}$ & $0.58^{* * *}$ & $0.36^{* * *}$ \\
\hline & $(-0.1)$ & $(-0.07)$ & $(-0.06)$ & $(-0.1)$ & $(-0.07)$ & $(-0.08)$ & $(-0.08)$ \\
\hline \multirow[t]{2}{*}{ Maths hours } & -0.11 & 0.49 & 1.62 & -0.76 & 0.79 & 0.17 & $2.31^{* *}$ \\
\hline & $(-0.42)$ & $(-0.53)$ & $(-1.1)$ & $(-0.47)$ & $(-0.69)$ & $(-0.44)$ & $(-1.12)$ \\
\hline \multirow{2}{*}{$\begin{array}{l}\text { Student-Teacher } \\
\text { Ratio }\end{array}$} & 0.78 & -0.33 & 0.05 & 0.15 & -0.08 & $0.36^{*}$ & -0.11 \\
\hline & $(-0.58)$ & $(-0.23)$ & $(-0.19)$ & $(-0.2)$ & $(-0.21)$ & $(-0.21)$ & $(-0.24)$ \\
\hline \multirow{2}{*}{$\begin{array}{l}\text { School mean } \\
\text { (ESCS) }\end{array}$} & $30.40 * * *$ & $19.88^{* * *}$ & $22.04 * * *$ & $26.42^{* * *}$ & $17.68^{* * *}$ & $19.95^{* * *}$ & $32.18^{* * *}$ \\
\hline & $(-5.21)$ & $(-5.6)$ & $(-4.38)$ & $(-7.82)$ & $(-4.47)$ & $(-4.11)$ & $(-6.39)$ \\
\hline \multirow[t]{2}{*}{ Constant } & $429.61^{* * *}$ & $447.79 * * *$ & $456.35^{* * *}$ & $377.15^{* * *}$ & $436.56^{* * *}$ & $399.98^{* * *}$ & $480.28^{* * *}$ \\
\hline & $(-13.9)$ & $(-11.78)$ & $(-8.55)$ & $(-16.42)$ & $(-12.25)$ & $(-11.51)$ & $(-12.41)$ \\
\hline \multirow[t]{2}{*}{ Ins1_1_1 } & $3.31^{* * *}$ & $3.23^{* * *}$ & $3.29 * * *$ & $3.09 * * *$ & $3.27^{* * *}$ & $3.16^{* * *}$ & $3.27^{* * *}$ \\
\hline & $(-0.09)$ & $(-0.08)$ & $(-0.1)$ & $(-0.19)$ & $(-0.11)$ & $(-0.08)$ & $(-0.09)$ \\
\hline \multirow[t]{2}{*}{ Insig_e } & $4.09^{* * *}$ & $4.03^{* * *}$ & $3.96^{* * *}$ & $3.91^{* * *}$ & $4.10^{* * *}$ & $4.08^{* * *}$ & $4.12^{* * *}$ \\
\hline & $(-0.01)$ & $(-0.01)$ & $(-0.01)$ & $(-0.03)$ & $(-0.02)$ & $(-0.02)$ & $(-0.02)$ \\
\hline Sample size $(n=)$ & 4,529 & 7,647 & 4,803 & 2,370 & 5,734 & 4,869 & 3,782 \\
\hline
\end{tabular}

Standard errors in parentheses *** $p<0.01,{ }^{* *} p<0.05,{ }^{*} p<0.1$

Source: authors' work. 
Table 5

\begin{tabular}{|c|c|c|c|c|c|c|c|}
\hline $\begin{array}{c}\text { Student } \\
\text { achievement }\end{array}$ & Chile & Colombia & Costa Rica & Dom Rep. & Mexico & Peru & Uruguay \\
\hline \multirow{2}{*}{$\begin{array}{l}\text { Male*Non-Hou- } \\
\text { sehold Labour }\end{array}$} & 0.57 & -2.4 & $-14.00 * * *$ & -4.36 & -1.88 & -5.87 & $-11.98^{* *}$ \\
\hline & $(-6.76)$ & $(-3.62)$ & $(-4.96)$ & $(-5.14)$ & $(-4.97)$ & $(-4.68)$ & $(-6.05)$ \\
\hline \multirow[t]{2}{*}{ Female } & $-28.75^{* * *}$ & $-27.46^{* * *}$ & $-25.72^{* * *}$ & $-14.27^{* * *}$ & $-14.37 * * *$ & $-22.24^{* * *}$ & $-29.39 * * *$ \\
\hline & $(-3.37)$ & $(-3.03)$ & $(-3.27)$ & $(-3.17)$ & $(-2.59)$ & $(-2.83)$ & $(-4.57)$ \\
\hline \multirow{2}{*}{$\begin{array}{l}\text { Household } \\
\text { Labour }\end{array}$} & -1.31 & -4.42 & 1.39 & 3.41 & 1.59 & $-8.12^{* *}$ & $-10.49^{* * *}$ \\
\hline & $(-3.13)$ & $(-2.77)$ & $(-2.86)$ & $(-4.35)$ & $(-3.5)$ & $(-4.09)$ & $(-3.68)$ \\
\hline \multirow{2}{*}{$\begin{array}{l}\text { Non-Household } \\
\text { Labour }\end{array}$} & $-27.53^{* * *}$ & $-22.18^{* * *}$ & $-9.66^{* *}$ & $-23.37^{* * *}$ & $-20.96^{* * *}$ & $-21.73^{* * *}$ & $-19.07^{* * *}$ \\
\hline & $(-4.58)$ & $(-2.67)$ & $(-4.46)$ & $(-4.17)$ & $(-4.01)$ & $(-3.79)$ & $(-4.83)$ \\
\hline \multirow[t]{2}{*}{ ESCS } & $9.50^{* * *}$ & $5.47^{* * *}$ & $6.63^{* * *}$ & $5.80^{* * *}$ & $4.16^{* * *}$ & $6.99 * * *$ & $8.48^{* * *}$ \\
\hline & $(-1.57)$ & $(-1.6)$ & $(-1.2)$ & $(-1.88)$ & $(-1.25)$ & $(-1.58)$ & $(-1.96)$ \\
\hline \multirow[t]{2}{*}{ Private } & -4.83 & 0.65 & -2.89 & 2.92 & -11.48 & -3.7 & -2.07 \\
\hline & $(-9.79)$ & $(-7.35)$ & $(-10.14)$ & $(-11.25)$ & $(-9.11)$ & $(-7.57)$ & $(-9.67)$ \\
\hline \multirow[t]{2}{*}{ GRADE } & $30.82^{* * *}$ & $23.71^{* * *}$ & $21.56^{* * *}$ & $17.97^{* * *}$ & $18.48^{* * *}$ & $22.72^{* * *}$ & $27.84^{* * *}$ \\
\hline & $(-3.07)$ & $(-1.14)$ & $(-2.02)$ & $(-1.8)$ & $(-3.89)$ & $(-1.4)$ & $(-2.21)$ \\
\hline \multirow{2}{*}{$\begin{array}{l}\text { Motivational } \\
\text { Level }\end{array}$} & 1.19 & $8.68^{* * *}$ & 2.25 & $5.37^{* *}$ & $6.37^{* * *}$ & $11.07 * * *$ & $9.24^{* * *}$ \\
\hline & $(-1.55)$ & $(-2)$ & $(-2.1)$ & $(-2.13)$ & $(-1.84)$ & $(-1.71)$ & $(-1.7)$ \\
\hline \multirow{2}{*}{$\begin{array}{l}\text { Exp Occupatio- } \\
\text { nal Status }\end{array}$} & $0.55^{* * *}$ & $0.22^{* * *}$ & -0.09 & 0.06 & $0.28^{* * *}$ & $0.58^{* * *}$ & $0.35^{* * *}$ \\
\hline & $(-0.1)$ & $(-0.07)$ & $(-0.06)$ & $(-0.1)$ & $(-0.07)$ & $(-0.08)$ & $(-0.08)$ \\
\hline \multirow[t]{2}{*}{ Maths hours } & -0.11 & 0.49 & 1.7 & -0.73 & 0.8 & 0.18 & $2.36^{* *}$ \\
\hline & $(-0.43)$ & $(-0.53)$ & $(-1.1)$ & $(-0.47)$ & $(-0.69)$ & $(-0.44)$ & $(-1.12)$ \\
\hline \multirow{2}{*}{$\begin{array}{l}\text { Student-Teacher } \\
\text { Ratio }\end{array}$} & 0.78 & -0.34 & 0.05 & 0.15 & -0.08 & $0.37^{*}$ & -0.12 \\
\hline & $(-0.58)$ & $(-0.23)$ & $(-0.19)$ & $(-0.2)$ & $(-0.21)$ & $(-0.21)$ & $(-0.24)$ \\
\hline \multirow{2}{*}{$\begin{array}{l}\text { School mean } \\
\text { (ESCS) }\end{array}$} & $30.42^{* * *}$ & $19.89^{* * *}$ & $21.99^{* * *}$ & $26.24 * * *$ & $17.66^{* * *}$ & $19.82^{* * *}$ & $32.14^{* * *}$ \\
\hline & $(-5.21)$ & $(-5.59)$ & $(-4.38)$ & $(-7.83)$ & $(-4.46)$ & $(-4.13)$ & $(-6.39)$ \\
\hline \multirow[t]{2}{*}{ Constant } & $430.39^{* * *}$ & $449.43^{* * *}$ & $457.80^{* * *}$ & $377.82^{* * *}$ & $436.43^{* * *}$ & $401.57^{* * *}$ & $478.92^{* * *}$ \\
\hline & $(-13.75)$ & $(-11.29)$ & $(-8.6)$ & $(-16.12)$ & $(-11.91)$ & $(-11.35)$ & $(-12.06)$ \\
\hline \multirow[t]{2}{*}{ Ins1_1_1 } & $3.31^{* * *}$ & $3.23^{* * *}$ & $3.29 * * *$ & $3.09 * * *$ & $3.27 * * *$ & $3.16^{* * *}$ & $3.27 * * *$ \\
\hline & $(-0.09)$ & $(-0.08)$ & $(-0.1)$ & $(-0.19)$ & $(-0.11)$ & $(-0.08)$ & $(-0.09)$ \\
\hline \multirow[t]{2}{*}{ Insig_e } & $4.09 * * *$ & $4.03^{* * *}$ & $3.96^{* * *}$ & $3.91^{* * *}$ & $4.10^{* * *}$ & $4.08^{* * *}$ & $4.12^{* * *}$ \\
\hline & $(-0.01)$ & $(-0.01)$ & $(-0.01)$ & $(-0.03)$ & $(-0.02)$ & $(-0.02)$ & $(-0.02)$ \\
\hline Sample size $(n=)$ & 4,529 & 7,647 & 4,803 & 2,370 & 5,734 & 4,869 & 3,782 \\
\hline
\end{tabular}

Standard errors in parentheses *** $p<0.01,{ }^{* *} p<0.05,{ }^{*} p<0.1$

Source: authors' work. 
Table 4 shows that there is no significant difference in achievement between males and females, on average, engaging in household labour across all 7 countries. The magnitude of the difference, although non-significant, is negligible. There is also no difference in outcomes between males who participate in household labour compared to those who do not except in the context of Uruguay. Boys engaged in household labour in Uruguay scored 15.7 points lower, on average. In Peru, they scored 7.24 points lower than boys who did not engage in household labour although the difference is not statistically significant. The findings are consistent for household labour participation effects from table 3 (which showed the average of both males and females) where only Uruguay and Peru had significant differences.

The results from Table 5 show that gender does not moderate the effects of engagement in non-Household labour on achievement outcomes except in the context of Costa Rice and Uruguay. The penalty of participating in non-household labour is significantly higher for males over females in Costa Rica and Uruguay (-14 and -11.98 points higher respectively). However, on an average for both males and females, participating in non-household labour is associated with lower outcomes (from table 3 and table 4). Table 5 reiterates the same findings with respect to the effects of household labour participation from table 3 and also additionally demonstrates the significantly lower outcomes among females who engage in non-household labour compared to those who do not.

Some of the broad observations which speak to literature regarding student education status are that, unlike in many other developing country contexts, attending a private school has shown no significant effect on average in all the above Latin American countries. The results also point broadly to poor quality education offered in secondary schools, as number of hours invested in studying by the student does not show any significant gains in their learning except marginally in Uruguay.

Lastly, although gender does not moderate the effects of household labour participation on student learning, it still remains as an influential category. The magnitude of influence gender has in shaping learning is at least 2.5 to 5 times more than that of socio-economic and cultural status, depending on the country. Girls are found to consistently underperform in comparison to boys in every Latin American country without exception. 


\section{Conclusion}

This study used international largescale assessment data (PISA) to highlight the trends and patterns in child labour participation in household and non-household activities in the seven Latin American countries. The results show a high level of participation, at least $65 \%$ in household activities and not less than $20 \%$ in non-household activities, in all countries in the sample. Furthermore, participation in household labour is not found to significantly affect students learning in majority of the countries except Peru and Uruguay.

Participation in non-household labour is shown to significantly hamper students' progress in learning across all of the seven countries of Chile, Colombia, Costa Rica, Dominican Republic, Mexico, Peru and Uruguay. This finding is in line with the findings of previous literature that non-household labour is a serious problem plaguing Latin American. Where previous studies have focused on the effect of child labour on school dropouts, repetitions of grade, attendance and years of schooling, this study contributes to knowledge by specifically demonstrating the magnitude of effect of participation in such activities on students learning levels, relative to other variables. It further adds how gender fails to moderate the household labour effects on learning and also in the case of non-household labour effects in majority of countries (except Costa Rica and Uruguay).

It does however point to gender as strongly associated with educational attainment, with girls underperforming boy across all countries despite literature positing that Latin America had in fact closed this gap, with female students even beginning to outperform males (Ahuja \& Filmer, 1995; Grant \& Behrman, 2010).

The strength of the study stems from the nature of survey data. The sample is representative for all the countries and measures of learning achievement are statistically sophisticated through inclusion of plausible values and appropriate sampling weights. This adds to the strength of generalisability of the results. The trends in participation levels, association and moderation between variables highlighted in the paper can be said to hold true for the entire population of 15-year olds in the above Latin American countries. Another strength of the study is the use of hierarchical modelling. In many of the empirical studies involving child labour, it is not common to account for the clustering of children's characteristics to estimate the effects of child labour on chosen outcomes.

The main weakness of the study is the measurement of participation in household and non-household activities using a binary scale. It collapses various forms of labour and duration of labour into a single category thereby 
impeding the further deciphering of the nature of activities across various countries or socio-economic categories. However, this lack of detail can be justified as the focus of the study is exclusively on education and we exploited the opportunity of the dataset capturing participation in labour albeit in a rudimentary form.

This study does not establish any causal relationship between participation in child labour (in household or non-household activities), or gender, or their interaction on the student achievement. This paper gives a potentially valuable perspective into the reality of the nature of association and trends across countries. However, a more rigorous identification strategy is needed to address the endogeneity problem to infer causality.

At age 15 (the age of all students participating in PISA) participation in the labour market is legal in all Latin American countries (Appendix 1). This is often only with authorisation from the inspectorate or local authority, but given the previously discussed lack of inspectors, it is doubtful whether the work conditions or hour limits are being enforced. This study shows that even potentially legal child labour may play a significant role in the regions' low educational attainment and should not be neglected in future work in the area.

The empirical trends and analysis can potentially contradict some of the theoretical understanding on the gendered nature of household activities or non-household activities. It challenges claims that household and non-household activities have differing effects for male and female education outcomes (except for Costa Rica and Uruguay in the contexts of non-household labour). There is inequality between genders in terms of achievement levels and also between those who participate in child labour (more significantly in non-household activities) and those who do not; however, the harmful effects of participating in non-household labour is not connected to gender. This is because the participation in non-household activities is undesirable irrespective of one's gender and there are other spheres of discrimination or decision-making which are potentially driving the inequality in learning outcomes between males and females that demand attention. Therefore, the focus for further research or policy ought to include other spheres of influence, or socio-economic dimensions to address the gender inequality in achievement levels.

[i] Brazil is omitted from the list due to large amount (approx. 45\%) of missing data in the category of labour participation in household and non-household domains.

It is also important to note that this study doesn't use the latest PISA 2018 data as the survey no longer includes variables pertaining to any forms of labour. 


\begin{tabular}{|c|c|c|c|c|c|c|c|}
\hline & Chile & $\begin{array}{l}\text { Colom- } \\
\text { bia }\end{array}$ & $\begin{array}{l}\text { Costa } \\
\text { Rica }\end{array}$ & $\begin{array}{l}\text { Domi- } \\
\text { nican } \\
\text { Rep. }\end{array}$ & Mexico & Peru & Uruguay \\
\hline School compulsory until & 17 & 15 & 16 & 13 & 17 & 16 & 14 \\
\hline Minimum Age for Work & 15 & 15 & 15 & 14 & 15 & 14 & 15 \\
\hline $\begin{array}{l}\text { Minimum Age for Hazar- } \\
\text { dous Work }\end{array}$ & 18 & 18 & 18 & 18 & 18 & 18 & 18 \\
\hline $\begin{array}{l}\text { Ratification of Interna- } \\
\text { tional Conventions on } \\
\text { Child Labour }\end{array}$ & $\checkmark$ & $\checkmark$ & $\checkmark$ & $\checkmark$ & $\checkmark$ & $\checkmark$ & $\checkmark$ \\
\hline
\end{tabular}

Source: ILAB, 2020.

\section{References}

Ahuja, V. \& Filmer, D. (1995). Educational attainment in development countries: New estimates and projections disaggregated by gender. Journal of Educational Planning and Administration X(3): 229-254

Altschul, I. (2012). Linking socioeconomic status to the academic achievement of Mexican American youth through parent involvement in education. Journal of the Society for Social Work and Research, 3(1), 13-30.

Archer, L., \& Francis, B. (2006). Understanding minority ethnic achievement: Race, gender, class and'success'. Routledge.

Arends-Kuenning, M., \& Duryea, S. (2006). The effect of parental presence, parents' education, and household headship on adolescents' schooling and work in Latin America. Journal of Family and Economic Issues, 27(2), 263-286.

Assaad, R., Levison, D., \& Zibani, N. (2010). The effect of domestic work on girls' schooling: Evidence from Egypt. Feminist Economics, 16(1), 79-128.

Bargain, O., \& Boutin, D. (2017). Minimum age regulation and child labor: New evidence from Brazil

Barnard, W. M. (2004). Parent involvement in elementary school and educational attainment. Children and youth services review, 26(1), 39-62.

Barone, F. J. (1993). The effects of part-time employment on academic performance. NASSP Bulletin, 77(549), 67-73.

Basu, K. (2005). Global labour standards and local freedoms. In WIDER perspectives on global development (pp. 175-200). Palgrave Macmillan, London.

Basu, K., \& Tzannatos, Z. (2003). The Global Child Labor Problem: What do we know and what can we do?. The world bank economic review, 17(2), 147-173.

Basu, K., \& Van, P. H. (1998). The economics of child labor. American economic review, 412-427. 
Beegle, K., Dehejia, R., \& Gatti, R. (2009). Why should we care about child labor? The education, labor market, and health consequences of child labor. Journal of Human Resources, 44(4), 871-889

Behrman, J., Duryea, S., \& Székely, M. (1999). Schooling investments and aggregate conditions: A household-survey-based approach for Latin America and the Caribbean. IDB-OCE Working Paper, (407).

Boockmann, B. (2010). The effect of ilo minimum age conventions on child labor and school attendance: Evidence from aggregate and individual-level data. World Development, 38(5), 679-692.

Bossuyt, N., Gadeyne, S., Deboosere, P., \& Van Oyen, H. (2004). Socio-economic inequalities in health expectancy in Belgium. Public health, 118(1), 3-10.

Card, D. (1999). The causal effect of education on earnings. In Handbook of labor economics (Vol. 3, pp. 1801-1863). Elsevier.

Chernikovsky, D., Lucas, R. E., \& Mueller, E. (1985). The household economy of rural Botswana: An African case. The World Bank.

Choi, A. (2018). De padres a hijos: expectativas y rendimiento académico en España. Presupuesto y gasto público, 90, 13-32.

Driessen, G., Smit, F., \& Sleegers, P. (2005). Parental involvement and educational achievement. British educational research journal, 31(4), 509-532.

Easterlin, R. A. (2003). Explaining happiness. Proceedings of the National Academy of Sciences, 100(19), 11176-11183.

Eckstein, Z., \& Wolpin, K. I. (1999) 'Why youths drop out of high school: the impact of preferences, opportunities, and abilities,' Econometrica 67, 1295-339

Edmonds, E. V., \& Shrestha, M. (2012). The impact of minimum age of employment regulation on child labor and schooling. IZA Journal of Labor Policy, 1(1), 14.

Gillborn, D., \& Mirza, H. S. (2000). Educational Inequality: Mapping Race, Class and Gender. A Synthesis of Research Evidence.

Gould, E. D. (2007). Cities, workers, and wages: A structural analysis of the urban wage premium. The Review of Economic Studies, 74(2), 477-506

Grant, M. J., \& Behrman, J. R. (2010). Gender gaps in educational attainment in less developed countries. Population and development review, 36(1), 71-89.

Grynspan, R. (2010). Foreword. In Declining inequality in Latin America: A decade of progress? (pp. Vi-Vii). Brookings Institution Press.

Guarcello, L., Lyon, S., \& Rosati, F. C. (2008). Child labor and education for all: An issue paper. The journal of the History of Childhood and Youth, 1(2), 254-266

Gunnarsson, V., Orazem, P. F., \& Sánchez, M. A. (2006). Child labor and school achievement in Latin America. The World Bank Economic Review, 20(1), 31-54.

Heymann, J., Raub, A., \& Cassola, A. (2013). Does prohibiting child labor increase secondary school enrolment? Insights from a new global dataset. International Journal of Educational Research, 60, 38-45. 
ILAB (2020). Findings on the Worst Forms of Child Labor. U.S. Department of Labor, Bureau of International Labor Affairs. Available at https://bit.ly/2Hwp3e2.

ILO (1996). What is child labour. International Programme on the Elimination of Child Labour (IPEC) Available at https://bit.ly/3oudwfR.

Khang, Y. H., Lynch, J. W., \& Kaplan, G. A. (2004). Health inequalities in Korea: age-and sexspecific educational differences in the 10 leading causes of death. International Journal of Epidemiology, 33(2), 299-308.

Kao, G., \& Thompson, J. S. (2003). Racial and ethnic stratification in educational achievement and attainment. Annual review of sociology, 29(1), 417-442.

Lee, J.-S., \& Bowen, N. K. (2006). Parent Involvement, Cultural Capital, and the Achievement Gap Among Elementary School Children. American Educational Research Journal, 43(2), 193-218. https://doi.org/10.3102/00028312043002193

Levison, D. (2000). Children as economic agents. Feminist Economics, 6(1), 125-134.

Lochner, L. (2011). Non-production benefits of education: Crime, health, and good citizenship (No. w16722). National Bureau of Economic Research.

Lochner, L., \& Moretti, E. (2004). The effect of education on crime: Evidence from prison inmates, arrests, and self-reports. American economic review, 94(1), 155-189.

López-Calva, L. F., \& Lustig, N. C. (Eds.). (2010). Declining inequality in Latin America: A decade of progress?. Brookings Institution Press.

Machin, S., Marie, O., \& Vujić, S. (2011). The crime reducing effect of education. The Economic Journal, 121(552), 463-484.

Marsh, H. W. (1991). Employment during high school: Character building or a subversion of academic goals?. Sociology of education, 172-189.

Montmarquette, C., Viennot-Briot, N., \& Dagenais, M. (2007). Dropout, school performance, and working while in school. The Review of Economics and Statistics, 89(4), 752-760.

Murillo, F. J. (2003). Una panorámica de la investigación iberoamericana sobre eficacia escolar. Revista Electrónica Iberoamericana sobre Calidad, Eficacia y Cambio en Educación, 1(1).

Nam, Y., \& Huang, J. (2009). Equal opportunity for all? Parental economic resources and children's educational attainment. Children and Youth Services Review, 31(6), 625-634

OECD (2017). PISA 2015 assessment and analytical framework: Science, reading, mathematic, financial literacy and collaborative problem solving. Organisation for Economic Cooperation and Development Publishing

Parent, D. (2006). Work while in high school in Canada: its labour market and educational attainment effects. Canadian Journal of Economics/Revue canadienne d'économique, 39(4), 1125-1150.

Pfeffer, F. T. (2018). Growing wealth gaps in education. Demography, 55(3), 1033-1068

Psacharopoulos, G. (1997). Child labor versus educational attainment Some evidence from Latin America. Journal of population economics, 10(4), 377-386. 
Putnick, D. L., \& Bornstein, M. H. (2016). Girls' and boys' labor and household chores in lowand middle-income countries. Monographs of the Society for Research in Child Development, 81(1), 104.

Reardon, S. F. (2011). The widening academic achievement gap between the rich and the poor: New evidence and possible explanations. In G. J. Duncan \& R. J. Murnane (Eds.), Whither opportunity? Rising inequality, schools, and children's life chances (pp. 91-115). New York, NY: Russell Sage Foundation

Rosenzweig, M. R., \& Evenson, R. (1977). Fertility, schooling, and the economic contribution of children of rural India: An econometric analysis. Econometrica: journal of the Econometric Society, 1065-10.

Rutkowski, L., Gonzalez, E., Joncas, M., \& von Davier, M. (2010). International large-scale assessment data: Issues in secondary analysis and reporting. Educational Researcher, 39(2), 142-151.

Ziol-Guest, K. M., \& Lee, K. T. (2016). Parent income-based gaps in schooling: Crosscohort trends in the NLSYs and the PSID. AERA Open, 2(2). https://doi.org/ $10.1177 / 2332858416645834$. 